\title{
THE EDUCATIONAL WORK OF NURSES IN THE FAMILY HEALTH STRATEGY ${ }^{1}$
}

\author{
Simone Roecker², Elisabete de Fátima Polo de Almeida Nunes³, Sonia Silva Marcon ${ }^{4}$
}

${ }^{1}$ Article based on the dissertation - O trabalho educativo do enfermeiro na Estratégia Saúde da Família no âmbito da $10^{\mathrm{a}}$ Regional de Saúde do Paraná, presented to the Nursing Master's Program at State University of Maringá (UEM), 2010.

${ }^{2}$ Master in Nursing. Professor of the Department of Nursing at Instituto Federal do Paraná. Paraná, Brazil. Email: moneroecker@ hotmail.com

${ }^{3}$ Ph.D. in Collective Health. Professor of the Collective Health Graduate Program at State University of Londrina. Paraná, Brasil. E-mail: alnunes@sercomtel.com.br

${ }^{4}$ Ph.D. in Nursing Philosophy. Professor of the Nursing Graduate Program at UEM. Paraná, Brazil. E-mail: soniasilva.marcon@ gmail.com

\begin{abstract}
This study has the objective of identifying nurses' perspectives regarding health education and investigating how it is conceived, planned, executed and evaluated in the Family Health Strategy. This is a descriptive-exploratory study, utilizing a qualitative approach. Data were collected from 20 nurses within the $10^{\text {th }}$ Regional Health Department of Paraná, through semi-structured interviews which took place in April of 2010, and then subjected to content analysis. Results demonstrate that while developing health education, nurses face many difficulties, which they mainly attributed to the absence of systematization and educational pedagogy regarding their academic education. In conclusion, given these obstacles, nurses require motivation and seek knowledge about planning, exercising and evaluating educational actions strategies, in addition to developing them with a view to improving life conditions and promoting health within the Family Health Strategy.
\end{abstract}

DESCRIPTORS: Health education. Family health. Public health nursing. Primary health care. Nurse's role.

\section{O TRABALHO EDUCATIVO DO ENFERMEIRO NA ESTRATÉGIA SAÚDE DA FAMÍLIA}

RESUMO: Este estudo objetivou identificar a perspectiva dos enfermeiros quanto à educação em saúde e averiguar como esta é concebida, planejada, executada e avaliada na Estratégia Saúde da Família. Trata-se de um estudo descritivo-exploratório, com abordagem qualitativa. Os dados foram coletados junto a 20 enfermeiros no âmbito da $10^{a}$ Regional de Saúde do Paraná, por meio de entrevistas semiestruturadas, em abril de 2010, e submetidos à análise de conteúdo. Os resultados mostram que os enfermeiros, ao desenvolverem educação em saúde, se deparam com diversos entraves que são atribuídos, especialmente, a ausência de sistematização e de tendências pedagógicas educativas desde a formação acadêmica. Conclui-se que, mesmo diante destes obstáculos, os enfermeiros precisam ser estimulados a buscar conhecimentos sobre estratégias de planejamento, execução e avaliação das ações educativas, além de desenvolvê-las no intuito de melhorar as condições de vida e promover a saúde da população no âmbito da Estratégia Saúde da Família. DESCRITORES: Educação em saúde. Saúde da família. Enfermagem em saúde pública. Atenção primária à saúde. Papel do profissional de enfermagem.

\section{TRABAJO EDUCATIVO DE LOS ENFERMEROS DE SALUD DE LA FAMILIA}

RESUMEN: Este estudio tuvo como objetivo identificar la perspectiva de los enfermeros en la educación para la salud y explorar la forma en que está concebido, planificado, ejecutado y evaluado en la Estrategia de Salud de la Familia. Se trata de un estudio exploratorio descriptivo con enfoque cualitativo. Se recogieron datos de 20 enfermeros en el décimo de Salud Regional de Paraná, a través de entrevistas, en abril de 2010 y sometido a análisis de contenido. Los resultados muestran que las enfermeras, en el desarrollo de la educación en salud, se enfrentan a muchas barreras que están afectados, sobre todo, la ausencia de tendencias sistemáticas y la educación pedagógica de la educación académica. Llegamos a la conclusión de que, a pesar de estos obstáculos, las enfermeras deben ser alentados a buscar el conocimiento acerca de la planificación, ejecución y evaluación de actividades educativas, y desarrollarlos con el fin de mejorar las condiciones de vida y promover la salud de la población en marco de la Estrategia Salud de la Familia.

DESCRIPTORES: Educación en salud. Salud de la familia. Enfermería en salud pública. Atención primaria de salud. Rol de la enfermera. 


\section{INTRODUCTION}

Primary Health Care (PHC) was proposed to prevent illnesses and promote health to the population of all ages and life stages; however, it is permeated by curative and biologist care values that are mainly focused on illness. However, the search for other care models occurs within a social and historical period, when the hospital and illness- guided model is no longer meeting the needs for modern world transformations, and the families and individuals' needs for health. Therefore, changes in health care models have emerged in Brazil. In 1994, the Family Health Program (FHP) was created as a team and family-centered model, 1 currently known as the Family Health Strategy (FHS).

This new health care model had the objective of reorganizing health care, guided by a humanized approach and affecting all healthcare system services. For this reason, the proposal was considered to be the main PHC strategy, with a subsequent reorganization of the family care model. ${ }^{2}$

Health professionals work daily with people who have a life reference, values and established beliefs; however, in many cases this knowledge and their personal experiences were not taken into consideration. Therefore, in order to work within a health education context in the communities, it is extremely important for professionals to establish a relationship among health, social and educational sciences, with the objective to promote democratic educational opportunities, respecting individual liberty and increasing awareness at the same time. ${ }^{3-4}$

Educational health promotion includes activities aimed at the development of individual and collective abilities with a view to improving health quality of life. Thus, among FHS actions, educational activities emerge as essential tools to stimulate each individual's self-care and selfesteem, and beyond that, the whole family and the community, promoting reflections that will guide clients' conducts and encourage change. ${ }^{5}$

In addition to being an inherent activity in the nursing profession and also proposed by the FHS, professional practice law, sanctioned previously during the creation of this new PHC model, states in article 11 that it is the nurses' responsibility as part of the health team to acquire health education with a view to improving the health of clients, families and the population in general. ${ }^{6}$

Given the limited publications surrounding the nursing work process and FHS health educa- tion, this present study had the objective to identify nurses' perspectives regarding health education and investigate how it is conceived, planned, exercised and evaluated in nurses' daily working routine in the FHS.

\section{METHODOLOGY}

This present study, a descriptive-exploratory research with a qualitative approach, is part of a larger research project named: "Health care and education work in nurses' daily routine in FHS - characteristics and challenges", financially supported by Fundação Araucária.

The state of Paraná has 399 municipalities, which are divided into 22 Regional Health Departments (RHDs). Hence, this present study was performed in the $10^{\text {th }} \mathrm{RHD}$, with headquarters in the city of Cascavel, and is comprised of $25 \mathrm{mu}$ nicipalities.

For the purposes of this study, the municipalities comprising the $10^{\text {th }} \mathrm{RHD}$ were divided into five groups according to their population size: less than 5,000 inhabitants (six municipalities); from 5,000 to 10,000 inhabitants (ten municipalities); from 10,000 to 20,000 inhabitants (seven municipalities); from 20,000 to 35,000 inhabitants (one municipality); and more than 35,000 inhabitants (one municipality).

In determining which municipalities would be included in the study, a random draw of two municipalities from the first three groups was performed and the two larger municipalities were included. The reason for this is that having distinct population characteristics results in differentiated capacities for delivering health care to the population, which may determine nurses' educational work and performance. Moreover, we did not have enough time and resources to perform the study in all RHD municipalities.

All nurses working in the FHS of the included municipalities in this study could have been participants, as long as they met the following inclusion criteria: being part of a complete FHS team and working in that same team for a minimum of five months. The time period was defined by the researchers with a view to interviewing nurses who had knowledge about the reality and health education needs of the population in the study area. Thus, from a total of twenty-seven active FHS nurses from the selected municipalities, twenty took part in this study, considering that four nurses failed to meet the inclusion criteria, 
one was on vacation, one on health leave and one declined to take part in the study.

Data were collected throughout the month of April 2010 by previously booked semi-structured interviews, which took place over the phone, according to the participants' availability. Interviews were guided by a semi-structured scheme composed of two parts: the first part included objective questions concerning the subjects' sociodemographic profile; and the second part included open-ended questions related to health education and the population. After the researcher's explanation of the purpose of the study, the Free and Informed Consent Form was signed by participants; afterwards, interviews were performed and digitally recorded.

Characterization data were descriptively analyzed and qualitative data were interpreted by category. ${ }^{7}$ First, gross data from the interviews were analyzed through broad reading, and then deep readings were performed to allow for the organization of data by grouping similar and diverging points, resulting into categories. Data discussion was performed afterwards, using the existing scientific publications regarding the theme as reference, with the aim of drawing conclusions concerning the FHS nurses' education and work characteristics.

The study was performed according to the requirements of Resolution 196/96 of the National Council of Health, with the appreciation and approval of the Permanent Human Research Ethics Committee of the State University of Maringá (statement n. 659/2009). Moreover, with the objective of differentiating the research subjects and preserving anonymity, participants were identified by the letter ' $E$ ", followed by an Arabic number indicating the order in which they were interviewed.

\section{RESULTS AND DISCUSSION}

First, the nurses' sociodemographic profile was described, with a view to characterizing the study population. Then, two broad categories were identified through content analysis: "Nurses perspectives regarding the educational work of the FHS" and "Health education systematization in the view of active nurses of the FHS".

Of the 20 nurses interviewed in this study, most were females (19), twelve were within the 22 to 30 year age bracket and the others (8) fell within the 31 to 45 year age bracket. Of the total, twelve were married, six were single, one was in a consensual relationship and one was divorced. Eleven interviewees had no children, and the others had one (4) or two (5) children.

Concerning professional information, most interviewees (13) graduated from public universities, and the number of years since graduation varied from five to 20 years (13); seven had recently graduated between one and four years ago.

Most subjects (19) had a lato sensu (specialization) graduate degree within several distinct areas, predominantly public health (12). When asked about the approach to health education in the graduate degree program, most (15) answered that health education was covered in the program, while four stated that it was not approached during the course.

The current working time in the unit varied between five months and eight years. Regarding work conditions, seventeen were hired through public tender and only three were hired in accordance with consolidation of labor laws. Of the twenty nurses interviewed, only two had more than one job, one was a nursing instructor and another worked in a hospital. Monthly family income showed a predomination (11) of six to nine minimum salaries, five fell within three to five salaries and four had an income above ten minimum salaries. Most (17) had two to five dependents to support with this income. Regarding training provided for FHS work, only five reported receiving training regarding the work of FHS and the nurses' function in this care model.

\section{Nurses' perspectives concerning the educational work of the FHS}

Health education is the main tool for the construction of a human being, valuing work practice beyond the biologic value and giving proper value to the social, emotional and spiritual being. Thus, as subjects in this study were questioned, it was determined that the educational work was developed with great expectations; in other words, as health education is performed, professionals hope to achieve good results: our greatest expectation is to awaken an interest for information. That they will understand our guidelines and they can be used to improve their own health conditions, and the family's and the whole community, promoting everyone's health. So, if they understand all this, our actions will provide good results (E14).

As educational actions are performed, nurses hope to reach (or exceed) the planned objectives, 
in which people value the nurses' work, actively participate in interventions and understand the guidelines, as well as the importance of caring for their own health and the community in general. It is important that people grasp that following the guidelines may result in improvement in overall health, a reduction in illness and a positive effect on peoples' lives.

Educational interventions, in addition to having health benefits for the population served, lead to results that positively favor the work of the entire team. Acknowledging that daily actions are positively affecting the work stimulates and encourages the professionals to perform them. Within the FHS, apart from actions based on positive results, health education is viewed as a practice that is the responsibility of all professionals in the team. ${ }^{8}$

Therefore, the search for a better quality of life is seen as a perpetual wish for mankind, and harmony among individuals, nature and the environment must be established. As a result, health education may influence people's knowledge, with a view to developing critical thinking and the ability to intervene in their own lives, and also the environment in which they interact. In this way, they can move closer to their own existence, as well as their citizenship. ${ }^{9}$

\section{Systematization of health education in the view of active FHS nurses.}

Since health education is an essential item in work development for FHS nurses, it is performed according to the knowledge acquired during professional education and the experience of each worker, under a non-specific regulation and with no standard methodology. The educational work phases of the nurses and their teams are presented below: diagnosis, planning, execution and evaluation.

\section{Diagnosis of educational needs}

In this present study, educational demands emerged mostly from the needs observed by health professionals during the course of their daily activities and by the data extracted from the population features previously described: I think that first we must survey the population, the area and the type of pathology to determine the needs of the population, acknowledging the population (E1).
Nurses who work in the FHS must, above all, learn about the population in question within their acting area. This can be accomplished by observing people while providing care, whether in the health unit or in their homes. Hence, by observations, including demographic, social and epidemiologic profiles, and also by talking to individuals in the community, nurses and the team are able to acknowledge the population's needs and therefore determine educational priorities.

Therefore, studying territorial features is a basic step in characterizing the population and their health problems, and also assists in evaluating the impact of their services at different levels of health care. Moreover, it allows nurses to develop links between guided health services by analysis of geographic scopes. ${ }^{10}$

In addition to emerging from nurses' observations of the population, education needs may also be identified from the daily work of the multidisciplinary team: here, most ideas come from team meetings, where we meet weekly and each CHA reports on his visits. Then we discuss the most severe cases and decide to work on that theme according to the main needs and also based on home visits (E14).

Ideally, the diagnoses of the educational health needs of the population come from observing people's lifestyle habits and actions as they are planned. Determining factors in the health/illness process are considered with a view to positively affecting the lives of individuals, families and the community.

Educational work includes teaching people to care for their own health, in such a way as to make them understand the causes and consequences of the pathologic event. Connected to this, professionals may make individuals aware of the importance of health care, of knowing how to care for themselves and gain a fuller understanding of the illness/health process. ${ }^{11}$

Identification of educational needs through multidisciplinary work is more effective, since it includes not only the observations of one person, but those of the entire team, who knows and lives with the population. In this present study, the work of community health agents (CHAs) is highlighted, since they reside in the FHS area, are in constant contact with the population and have first-hand knowledge of the community and its needs.

In addition to the aforementioned methods of planning and identification of health needs, the 
ideal scenario would include the opinions of the citizens: so, the need for working with the subject and with the communities comes from monthly meetings, mainly from those where representatives of the community participate (E20).

Among the twenty participants in this study, only one mentioned that educational actions were planned with the help of the population or their representatives. It demonstrates that actions are almost exclusively planned by professionals who judge the necessity of actions, disregarding the population's needs, which may be reflected in the non-adherence of clients to educational activities, in addition to demonstrating how distant FHS health education is from what is proposed by the Ministry of Health.

A study demonstrates that educational work proposals must count on the participation of the population, with the aim of developing knowledge regarding health education. Consequently, communication is an important instrument, capable of instigating, informing and connecting individuals to develop their critical thinking. ${ }^{9}$

To their credit, nurses know how to diagnose the educational needs of the population, but in practice this does not always occur: the correct thing would be for us, as the team, through the CHA and epidemiological data, to determine which are the community's problems, but that's not what is done. I present the problem I think is important, book a meeting, and prepare a presentation (E10).

Education should be planned as a social interaction process, occurring in the relationship between individuals and their reality and the world they are living in. Therefore, "questions involving health education must promote an individual sense of identity, autonomy, dignity, responsibility, solidarity and, above all, community responsibility and rescue of citizenship". 9:158

\section{Planning educational actions}

After diagnosing the need for health educational activities with the population in this study, particularly collective actions, the ideal situation would be to plan activities based on discussions as a team: we try to meet with the team to discuss and plan the activities together. So sometimes I develop some things from my own knowledge and then I elaborate activities and execute them, both alone and with the team (E11).

Despite the fact that in this study we identified that FHS team members' work, mainly nurses, is fundamental in meeting the demands of care delivery, in the Municipal Department of Health $(\mathrm{MDH})$ many professionals reported that they attempt to discuss and perform activities with all multidisciplinary team members; however, they also mentioned that the planning and structuring of work plans are still ineffective.

Therefore, health planning may be understood as the establishment of coordinated actions with a view to achieving a certain objective, solve problems, and discuss mechanisms of policy implementation, as well as construct plans, programs and projects. ${ }^{12}$

Based on the importance of creating work plans for the development of educational actions, we observed that only one of the twenty nurses in this study makes use of written plans: in the team meeting we discuss actions, create a rough draft and then add the essential, founded information. Then we put on paper all our projects, objectives, methodology and chronograms. We put everything in documents because we feel (me and the team) it is a way to accomplish and monitor what was planned (E15).

On the other hand, reports identified teams who do not utilize this method but acknowledge the relevance of this practice: [...] we do not create a written record, but I think it would be helpful and would assist us to accomplish the established objectives (E18).

Health planning is considered a signed agreement between interested parties. Everything that is planned and written is valid and must be executed. ${ }^{12}$ Hence, the importance of creating a written work plan to address the needs of the population should be evaluated; and along with this, performing and monitoring the execution of the plan should be done by the team members themselves, and by the community in general.

Reports demonstrate that after diagnosing the health needs of the population through surveying the educational needs, most teams (19) prepare materials and execute activities, with no development of an action plan as a way of registering and guiding educational actions: afterwards, a search for materials is done, using the Internet, posters, books and other sources. So we always work together, we ask for each other's opinion, for the help of the whole team, and then we execute [...] (E13).

The materials preparation phase that forms the basis for the nurses' and the team's educational practice, even without previous planning, is a crucial moment-- after verifying the educational needs, professionals will be prepared to disseminate information in order to improve people's 
health conditions, based on making them aware of the individual and collective need for self-care, autonomy, social control and identification and dominion over all determining factors in the illness/health process.

\section{The execution of educational interven- tions}

As participants were questioned concerning the work methodology used, and it was demonstrated that health education had no theoreticalpedagogical grounding: I do it as I feel it must be done, based on my work experience, I have no methodology or specific theory (E15).

Nurses develop their educational practice based on the knowledge they acquire throughout their education, and also on their place of employment's routines and demands in which they are immersed and seek to achieve their objectives.

Literature shows that the educational work developed by nurses is generally founded on each professional's comprehension of education according to their personal and work experience. Hence, many professionals who perform health education routinely have no knowledge of the pedagogical trends on which their educational practice is based. ${ }^{13}$

From the available literature regarding existing pedagogical trends, this present study adopted the Libâneo reference, ${ }^{14}$ which is classified into two groups: liberal pedagogy and progressive pedagogy. The first is comprised of the traditional pedagogies (progressive renewed, non-directive and technicist renewed), focused on learning individuals but attributing great importance to the teacher, with a vertical relationship in which the teacher has the knowledge and passes this knowledge on to their students. The second is comprised of free school, anarchist school and social criticism pedagogies, based on acquiring knowledge through interpersonal relationships and interactive activities (mainly group activities), in which individuals are believed to learn through their life experiences and teachers are mediators between knowledge and the learning subjects within a horizontal relationship. ${ }^{14}$

Parting from these pedagogical theories, progressive pedagogical trends are believed to be more appropriate for health education, since learning means developing the ability to absorb information and work under the stimulation of the environment as well as the interaction between individuals, with the objective to build education from a concrete situation in their lives. ${ }^{14}$

Hence, based on the Libâneo reference, ${ }^{14}$ the educational model adopted by nurses can be affirmed as being based on liberal pedagogy, and is still far from building what nurses see as an educational position based on progressive pedagogy.

In order to exercise the pedagogic action, it is extremely important for the nurse-teacher to reflect on and build their educational concept. This will give them a base on which to strengthen their pedagogical model and their teaching profile. Therefore, nursing education performed by FHS nurses must encourage critical, problem-solving, ethical and curiosity-guided thinking, dialogue, listening and the construction of shared knowledge. $^{15}$

Some reports emphasize the difficulties in developing health education, mainly due to the lack of a systematized approach to this practice from graduation to daily work, in which nothing is regulated for performing such a task, differing from what is presented in nursing care development using the steps of nursing care systematization (NCS): so I think that what we learn back in graduate school must be guided more towards health education. Because there is a nursing process, the NCS, where everything is systematized for health actions in the hospital environment; for health education, there is nothing, so we do it the way we think is the best [...] (E15).

It is understood that nursing professionals' education makes them unprepared to develop education health activities as they enter the FHS. Reports indicate great difficulties in describing the educational work performed and a lack of grounding methodology for health prevention and promotion actions for the families in the mentioned area. Only five nurses affirmed having specific preparation for working in the FHS, and this was perhaps a contributing factor for flaws in the execution of health education, considering that without training it is more difficult for professionals to understand working dimensions.

Health education is essentially a free education, aimed at reinforcing individuals' awareness about themselves and their reality. In order for it to take place and enable reflexive actions regarding health services, a middle ground between health professionals' techno-scientific knowledge and clients' popular knowledge must be reached. ${ }^{16}$

For educational activities nurses and other team members use materials and different meth- 
ods to execute health education. Conveying information orally is the most common method, followed by the use of fliers, posters, serial albums / flip charts, banners, and multimedia; for practical and demonstrative materials, professionals make use of what is available in the unit, such as human anatomy models: I use serial albums a lot, sometimes multimedia, some fliers that come from the RHD and some materials we created here, but normally I provide information by speaking and using practical materials. We have some posters and prototypes of the human body. Ah, I try to use images a lot, because I think that everything that is seen is better learned and absorbed (E11).

The resources used are normally those provided by the MDH to the health units, usually restricted to the use of images and lectures. As a consequence, nurses' reports show little to no use of group and/or interaction dynamics among group activity participants. Educational strategies are considered to be interactive dialogues. Group dynamics and ludic activities are tools that lead people to think and practice what is taught; therefore, they help to build concrete knowledge about health questions. This is a method that has been demonstrated to be effective, especially regarding strategies linked to health education and promotion. ${ }^{17}$

For most interviewees (14), the available resources in the unit are old and few in numbers. However, even given the many obstacles, some professionals are motivated and show interest in, along with the team, producing their own materials, searching for information and updating them: we don't have many resources, and those we have are old, so we have to make posters and other resources and we are updating them (E15).

Health education is still a poorly explored area for FHS professionals, due to the PHC model being little valued by users, professionals, municipal mangers and coordinators, especially since they present no imminent results.

Despite the remodeling of the care model, which is part of the new FHS policy, the model continues to be consolidated. For this reason, elements from both health care models, the curative and the preventive model, are still being included in planning and implementation strategies for health education. In general society, the idea that health services are associated with illness and not health prevention persists, making it even more difficult to move away from the biomedical health model. ${ }^{18}$
Educational actions are developed in many locations besides health units, according to the opportunities of each unit and also the population: I carry it out here in the unit, in the community center, in the school... We choose the place depending on the number of people, so as there are five communities here, I always have the activities in the community centers, and in the camps [two] we do the activities in the small health center they built for the health professionals (E15).

In most units, a space is delegated for educational practices, a fact that makes developing this work model difficult: when they plan the building, there is always a big meeting room for groups and all, but then they need to cut back costs and they choose to take out what they think is less important, which is generally the place for health education groups, meetings with the population; then we have to look for available places in the community, and the worst part is that these places are not always appropriate (E13).

Health education is demonstrated as being disregarded by managers even when planning the unit's construction or remodeling. Therefore, the question is: how can professionals be required to implement new health care models for people's health, founded on prevention and promotion, if the physical and material structures designated for this work do not meet the needs of this strategy?

Under this perspective, prior plans for the FHS are not being entirely reached and their consolidation is not being passed on. However, efforts are being employed by teams, even given these problems, with a view to reversing the health care model by valuing health instead of illness, including the adoption of new principles such as health promotion, including educational actions, community participation and social control. ${ }^{19}$

\section{The evaluation of educational actions}

All participants in this study evaluated health education as being beneficial to the population: I can't say how the population's health improved using a percentage parameter, but I think that health education has brought many positive results, slowly, but it has. (E6).

Evaluation of educational results is a continuous learning process, in which there must be an interaction among nurses, the team and clients in order to evaluate educational actions, identifying their success and the necessary changes that must be made, taking into account the impact of health education on people's lives. 
However, although most nurses mentioned not having a specific mechanism for evaluating health action results, some of them (10) believe health indicators built by the MDH (through monthly reports completed and sent by them) may provide information to identify improvements in the population's health conditions. Evaluation is certainly linked to performing educational actions that will stimulate and improve their health: I have no evaluation method, only observations we make regarding the population. Nothing specific, but I believe health indicators help us to evaluate our educational actions that we perform with the population. If they are improving it means our actions are effective (E17).

Educational actions are planned and executed by health professionals, according to their vision about the needs demonstrated by the population, but these are normally not monitored; in other words, there are no evaluation parameters to measure results of educational actions.

In parallel, improvements in peoples' health conditions, viewed by health indicators, are not attributed to the development of educational actions, even when they are an essential practice in the daily routine in the FHS.

\section{FINAL CONSIDERATIONS}

Results from this present study demonstrate that nurses, as they develop health education strategies, wish to improve the health and life conditions of the population, and that educational actions must be constantly and effectively executed with the population with a view to preventing illness, improving life and health conditions, and, consequently, promoting the population's health.

As educational work is developed, nurses face limitations within their own routine - mainly regarding the lack of regulation and devaluing of educational actions; in other words, the absence of educational practice standardization and the lack of knowledge regarding pedagogical trends that ground it. This makes it difficult for them to implement effective actions with the population within their daily work in the FHS.

Ideas discussed here may be used not only in the development of FHS educational work, but also in the education of new nursing professionals, and even in the reformulation and systematization of educational practices performed in many health services, especially at the primary health care level.

Given the above, this present work represents a small step in producing knowledge about the educational health process in the FHS, and makes performing new studies necessary with a view to revealing features of health education and providing care guided towards individual, families and the community's needs.

\section{REFERENCES}

1. Rosa WAG, Labate RC. Programa de saúde da família: a construção de um novo modelo de assistência. Rev Latino-am Enfermagem 2005 NovDez; 13(6):1027-34.

2. Ministério da Saúde (BR), Secretaria de Políticas de Saúde. 50 milhões de brasileiros atendidos. Rev bras saude família 2002 maio; edição especial; ano II(5):1-80.

3. Budó MLD, Saupe R. Conhecimentos populares e educação em saúde na formação do enfermeiro. Rev Bras Enferm. 2004 Mar-Abr; 57(2):165-9.

4. Pessanha RV, Cunha FTS. A aprendizagem-trabalho e as tecnologias de saúde na Estratégia Saúde da Família. Texto Contexto Enferm [online]. 2009 Abr-Jun [acesso 2010 Out 17]; 18(2). Disponível em: http://www.scielo.br/scielo.php?script=sci arttext\&pid=S0104-07072009000200005\&lng=pt

5. Machado MFAS, Monteiro EMLM, Queiroz DT, Vieira NFC, Barroso MGT. Integralidade, formação de saúde, educação em saúde e as propostas do SUS - uma revisão conceitual. Cien Saude Coletiva. 2007; 12(2):335-42.

6. Brasil. Lei $n^{0} 7.498$ de 25 de junho de 1986. Dispõe sobre a regulamentação do exercício da Enfermagem e dá outras providências. Diário oficial da União 1986; 25 jun.

7. Bardin L. Análise de conteúdo. Lisboa (PT): Edições 70; 2008.

8. Alves VS. Um modelo de educação em saúde para o Programa Saúde da Família: pela integralidade da atenção e reorientação do modelo assistencial. Interface: Comunic, Saude, Educ. 2004 Set-2005 Fev; 9(16):39-52.

9. Cecagno D, Siqueira HCH, Cezar Vaz MR. Falando sobre pesquisa, educação e saúde na enfermagem. Rev Gauch Enferm. 2005 Ago; 26(2):154-60.

10. Monken M, Barcellos C. Vigilância à saúde e território utilizado: possibilidades teóricas e metodológicas. Cad Saude Publica. 2005; 21(3):898-906.

11. Roecker S, Marcon SS. Educação em saúde na Estratégia Saúde da Família: o significado e a práxis dos enfermeiros. Esc Anna Nery. 2011; 15(4):701-09.

12. Paim JS, Teixeira CF. Política, planejamento e gestão em saúde: balanço do estado da arte. Rev Saude Publica. 2006; 40(Esp):73-8.

13. Alencar RCV. A vivência da ação educativa do enfermeiro no programa saúde da família (PSF) [dissertação]. Belo Horizonte (MG): Universidade 
Federal de Minas Gerais, Escola de Enfermagem; 2006.

14. Libâneo JC. Democratização da escola pública. A pedagogia crítico-social dos conteúdos. $19^{a}$ ed. São Paulo (SP): Loyola; 2003.

15. Guimarães GL. O perfil do enfermeiro-educador para o ensino de graduação. Esc Anna Nery. 2005 Ago; 9(2):255-60.

16. Acevedo MB, Becerra FN, Ospina JN, Paucar GE, Córdoba AA, Correa FP. El diálogo de saberes como posición humana frente al otro: referente ontológico y pedagógico en la educación para la salud. Invest Educ Enferm. 2009; 27(1):104-11.
17. Magalhães CR. O jogo como pretexto educativo: educar e educar-se em curso de formação em saúde. Interface: Comunic, Saude, Educ. 2007; 11(23):647-54.

18. Silva CP, Dias MS, Rodrigues AB. Práxis educativa em saúde dos enfermeiros da Estratégia Saúde da Família. Cienc Saude Coletiva. 2009; 14(Supl.1):1453-62.

19. Cordeiro H, Romano VF, Santos EF, Ferrari A, Fernandes E, Pereira TR, Pereira ATS. Avaliação de competências de médicos e enfermeiros das Equipes de Saúde da Família da Região Norte do Brasil. Physis. 2009; 19(3):695-710. 